\title{
ANALIZA PORTFELA RYZYK NA PODSTAWIE LOSOWO WYBRANYCH PRZEDSIĘBIORSTW W SEKTORZE MŚP
}

\author{
Monika Piśniak \\ Politechnika Częstochowska \\ Wydział Zarządzania
}

\begin{abstract}
Streszczenie: Pojęcie ryzyka znane jest ludzkości od zarania dziejów, na początku dotyczyło zapewnienia odpowiednich warunków do przeżycia, następnie wraz z rozwijającą się gospodarką stało się nierozerwalne z każdą dziedziną życia ludzi oraz przedsiębiorstwa. Celem opracowania jest klasyfikacja wraz $\mathrm{z}$ podziałem ryzyka występującego $\mathrm{w}$ procesach decyzyjnych, które są mocno związane z zarządzaniem. Powiązane jest przez to z nieznaną przyszłością, brakiem kompletnych informacji, które mają na celu eliminację ryzyka lub też jego zmniejszenie. W trakcie kolejnych następujących po sobie procesów, które mają miejsce, jako konsekwencja podjętej decyzji mogą wystąpić zakłócenia płynące ze środowiska naturalnego lub otoczenia społecznego, wywołując stan niepewności.

Celem przedłożonej pracy jest wskazanie, z jakimi rodzajami ryzyk mają styczność małe i średnie przedsiębiorstwa na każdym poziomie decyzyjnym. Dodatkowym celem opracowania jest pokazanie, jak znikoma jest wiedza dotycząca ryzyka w badanych przedsiębiorstwach.
\end{abstract}

Słowa kluczowe: ryzyko, rodzaje ryzyk, bariery, MŚP

DOI: 10.17512/znpcz.2016.2.16

\section{Wprowadzenie}

Ryzyko występuje w każdej dziedzinie życia człowieka, jest ono znane od początku dziejów. Powstaje, jeśli mamy do czynienia z sytuacją, w której należy podjąć decyzję, nie znając przyszłych skutków. Powiązane jest zatem z nieznaną przyszłością oraz brakiem kompletnych informacji, mających na celu eliminację ryzyka lub też jego zmniejszenie. W trakcie kolejnych procesów następujących po sobie w konsekwencji podjętej decyzji mogą wystąpić zakłócenia płynące ze środowiska naturalnego lub otoczenia społecznego, wywołując stan niepewności (Kaczmarek 2008, s. 48).

W momencie podejmowania decyzji nie dysponujemy nigdy kompletnym zbiorem informacji, jedynie wspieramy się danymi, które otrzymaliśmy z analizy historycznej. Zmusza to do odgadywania skutków oraz przyszłych rezultatów obecnych decyzji (Moore 1975, s. 15). Decyzje te podejmuje się, akceptując albo odrzucając założenia warunków, które opisują w pewnym przybliżeniu realia procesu decyzyjnego. Warunki te dzielą się na deterministyczne, czyli te, które są pewne, mogące przewidzieć wszystkie konsekwencje podejmowanych decyzji, oraz niedeterministyczne, którymi jest właśnie ryzyko oraz niepewność (Marcinkowski 2009, s. 113). 
Przeglądając literaturę przedmiotu, można znaleźć wiele różnorodnych klasyfikacji ryzyka, najbardziej ogólny podział to na ryzyko rynkowe oraz specyficzne (Schroeck 2002, s. 2). Ryzyko specyficzne jest związane ze specyfiką poszczególnych przedsiębiorstw, natomiast rynkowe wyrażane jest za pomocą kowariancji odchyleń pojawiających się zmian w ogólnym rozwoju gospodarczym (Zachorowska 2006, s. 59).

Według W. Tarczyńskiego oraz M. Mojsiewicza można wyodrębnić trzy podstawowe rodzaje ryzyka (Tarczyński, Mojsiewicz 2001, s. 15-16):

- Właściwe, oparte jest na zasadzie wielkich liczb.

- Subiektywne, wyraża się za pomocą niedoskonałości człowieka, przez to może przejawiać się subiektywizmem podczas szacowania prawdopodobieństwa wystąpienia określonego zjawiska;

- Obiektywne, będąc związane ze stanem niepewności, określa zupełny brak możliwości przewidzenia zdarzeń.

Analizując definiowanie ryzyka w dostępnej literaturze, można zauważyć, że jest ono zarówno pojęciem intuicyjnym, jak i mierzalnym, spowodowane jest wieloma różnicami subiektywnymi definiujących (Malara 2013, s. 11-12). Sprowadzają się one do różnic semantycznych (Piśniak 2014, s. 7), jednak w niektórych można zauważyć element operacyjny.

Pojęcie ryzyka pochodzi z łacińskiego słowa „riscare”, które znaczy „odważyć się", nakreślając kluczowe znaczenie ryzyka jako kwestii wyboru, a nie przeznaczenia (Bernstein 1997, s. 19).

Wspótczesny stownik języka polskiego podaje definicję, że ryzyko to „możliwość sukcesu, ale także niepowodzenia, porażki, straty. To także przedsięwzięcie, którego wynik jest niepewny, wątpliwy. Ryzyko to również możliwość powstania szkody" (Dunaj (red.) 1998, s. 598).

Uzupełnieniem definicji podanej przez słownik języka polskiego jest opis pochodzący z Encyklopedii organizacji i zarządzania, mówiący, że wielkość ryzyka jest zdeterminowana poprzez: typ, zakres, a także warunki, w jakich proces przebiega (Pasieczny 1981, s. 410).

\section{Analiza uzyskanych wyników badania portfela ryzyk w MŚP}

Kwestionariusze składają się z czterech części; poza jednym pytaniem otwartym, wszystkie pytania są zamknięte. Zostały one wysłane drogą elektroniczną do 56 przedsiębiorstw, niestety nie wszystkie zostały wypełnione oraz przesłane zwrotnie. Większość odpowiedzi zwrotnych stanowiły thumaczenia o braku potrzeby zajmowania się w organizacji ryzykiem, dlatego też respondenci nie wypełnili ankiet.

Liczebność próby uzasadniona została doborem celowym - wszystkie przedsiębiorstwa deklarowały, że zajmują się w ramach prowadzenia swojej działalności zarządzaniem ryzykiem.

Ankieta została podzielona na cztery części: pierwsza dotyczyła danych o ankietowanym przedsiębiorstwie, druga danych o ankietowanym, trzecia to identyfikacja i podział ryzyka, a czwarta dotyczyła podejścia do ryzyka oraz związanych $\mathrm{z}$ nim barier. 
1) Podstawowe dane o ankietowanej firmie

Najczęściej ankietowani zatrudnieni są w organizacjach sektora prywatnego, bo aż ponad $70 \%$, natomiast niecałe $30 \% \mathrm{w}$ organizacjach publicznych. Nikt z pytanych osób nie pracuje w organizacjach sektora porządkowego. Wyniki odpowiedzi na to pytanie zostały przedstawione na wykresie (Rysunek 1).

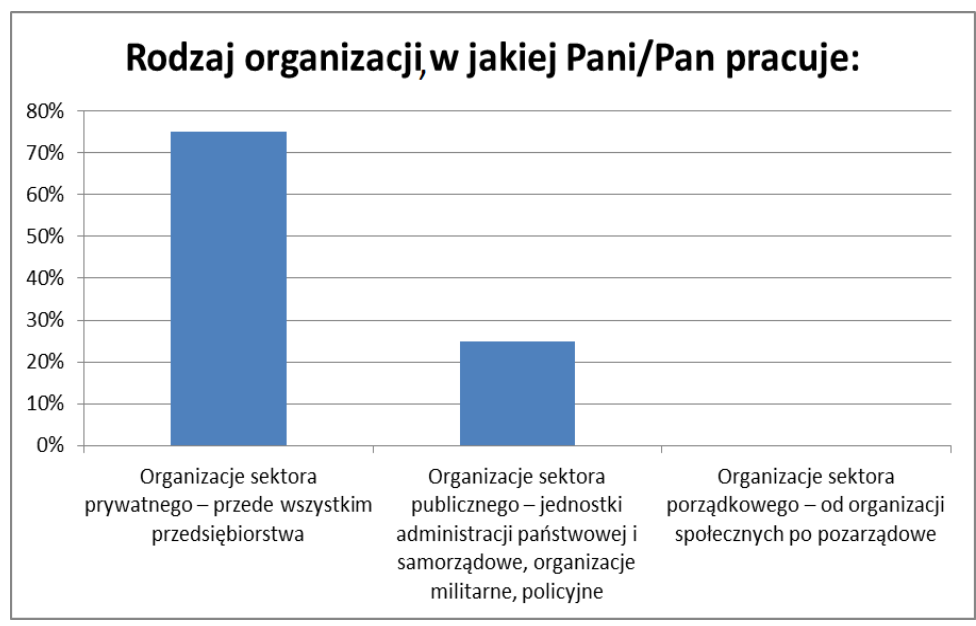

Rysunek 1. Ujęcie procentowe rodzaju organizacji, w jakiej ankietowany pracuje

Źródło: Opracowanie własne

Kolejne pytanie dotyczyło współpracy opartej na wymianie doświadczeń z innymi formami czy też ośrodkami badawczymi. Poniższe odpowiedzi (Rysunek 2) cieszą, ponieważ wynika z nich, że istnieje współpraca u $100 \%$ ankietowanych. Najczęściej dotyczy firm krajowych, ewentualnie UE. Szkoda, że tylko niecałe $10 \%$ współpracuje z ośrodkami akademickimi.

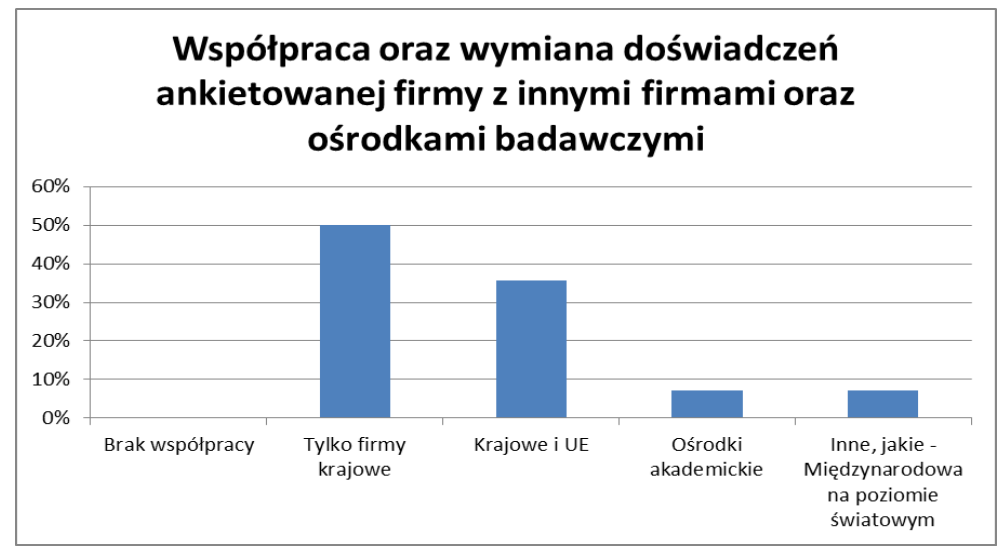

Rysunek 2. Przedstawienie procentowe współpracy oraz wymiany doświadczeń ankietowanej firmy $z$ innymi firmami oraz ośrodkami badawczymi

Źródło: Opracowanie własne 
Przede wszystkim, jak wskazują odpowiedzi przedstawione na Rysunku 3, ankietowani byli pracownicy zatrudnieni w organizacjach o pozycji lokalnej, co dziwne - kolejną odpowiedzią co do wysokości wyników była ta dotycząca pozycji firmy w skali europejskiej. Namniej punktów otrzymała grupa znacząca w kraju.

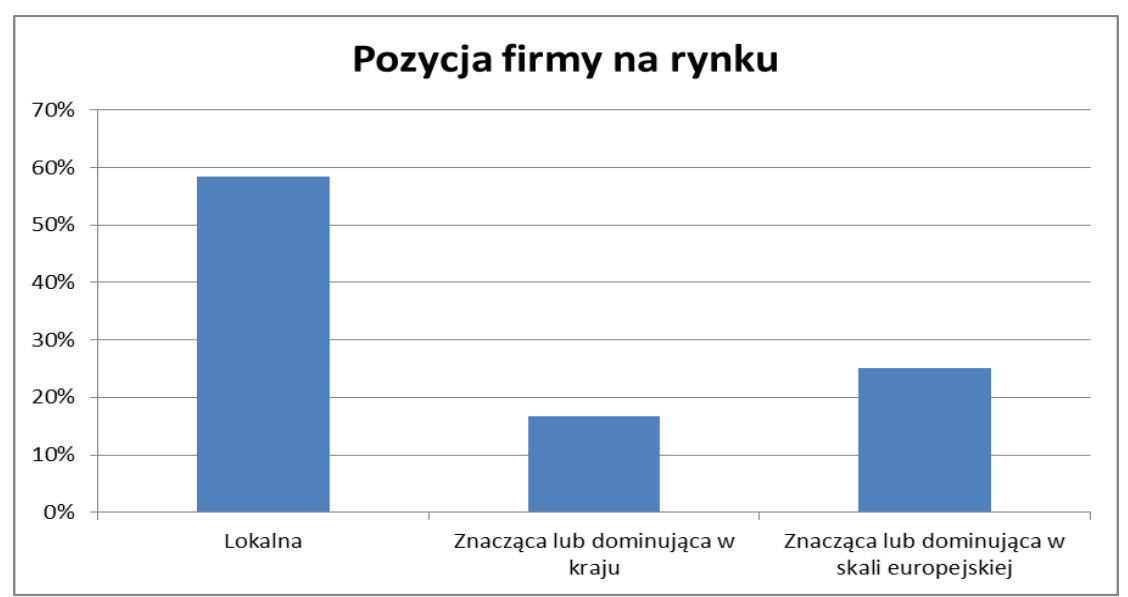

Rysunek 3. Procentowy układ pozycji ankietowanych firm na rynku

Źródło: Opracowanie własne

2) Pytania dotyczące identyfikacji oraz rodzaju ryzyka

Pierwszym pytaniem rozpoczynającym tę część ankiety jest pytanie otwarte, dotyczące skojarzeń ze słowem „ryzyko”. Tak jak wskazuje Rysunek 4, uzyskano sporo różnych odpowiedzi. Jedyne, co można zauważyć, to tendencja do słów: „niepewność”, „niepewna sytuacja” itp. Często też ryzyko rozumiane jest przez respondentów jako strata czy zagrożenie.

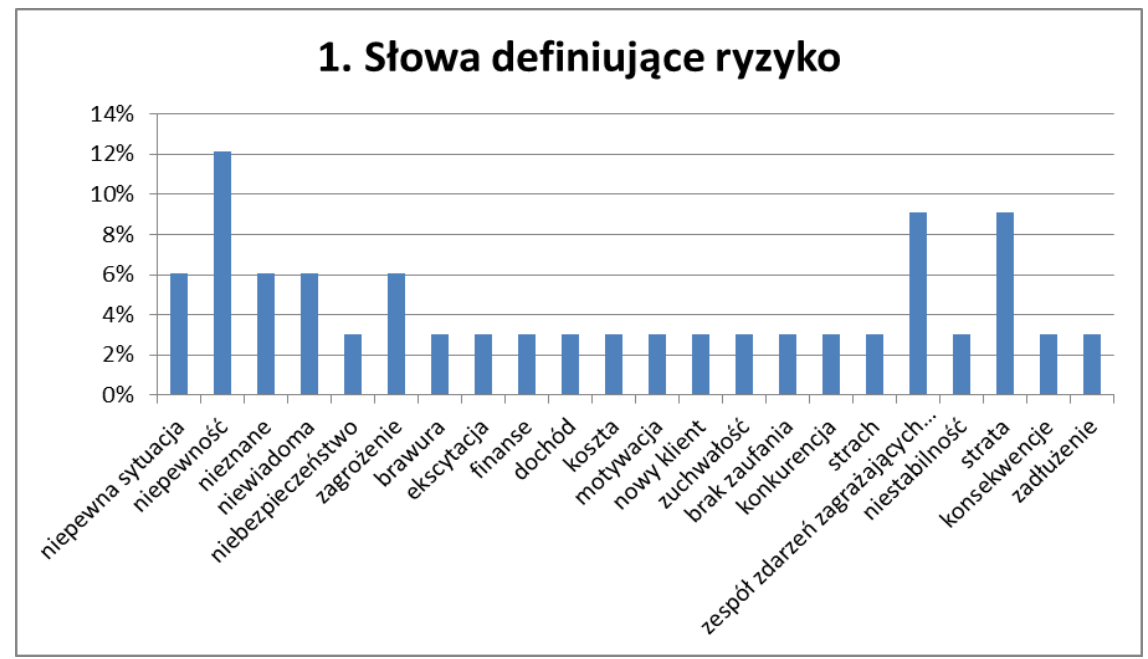

Rysunek 4. Wykres procentowy pokazujący, jak ankietowani definiują ryzyko

Źródło: Opracowanie własne 
Poniższe pytanie dotyczyło kwestii odpowiedzialności za identyfikację ryzyka w organizacji. Dokładnie połowa ankietowanych wskazała całą jednostkę (Rysunek 5), ok. $25 \%$ respondentów - wybrany obszar, $15 \%$ nie ma zdania, a niecałe $10 \%$ konkretny projekt, program.

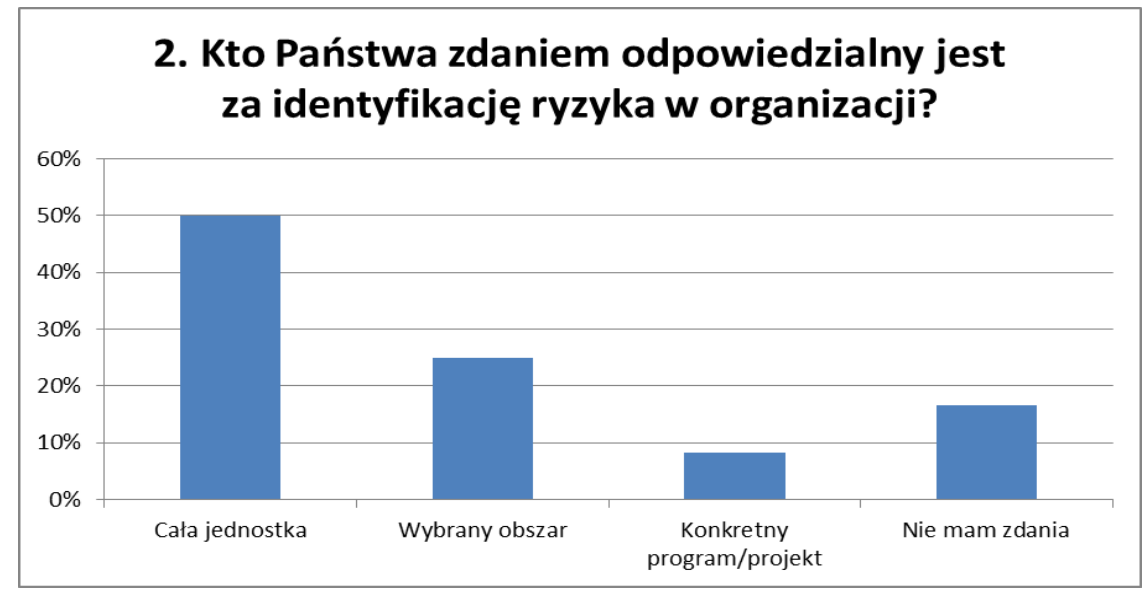

Rysunek 5. Przedstawienie procentowe, kto według ankietowanych odpowiedzialny jest za identyfikację ryzyka w organizacji

Źródło: Opracowanie własne

Natomiast odpowiedzi na to pytanie, które zostało specjalnie sformułowane inaczej, nie pokrywają się z odpowiedziami powyżej. Tym razem nie pojawiła się odpowiedź „nie mam zdania”; najwięcej bo ponad $40 \%$ respondentów wskazuje wyznaczone osoby, jako odpowiedzialne za identyfikację ryzyka (Rysunek 6 ).

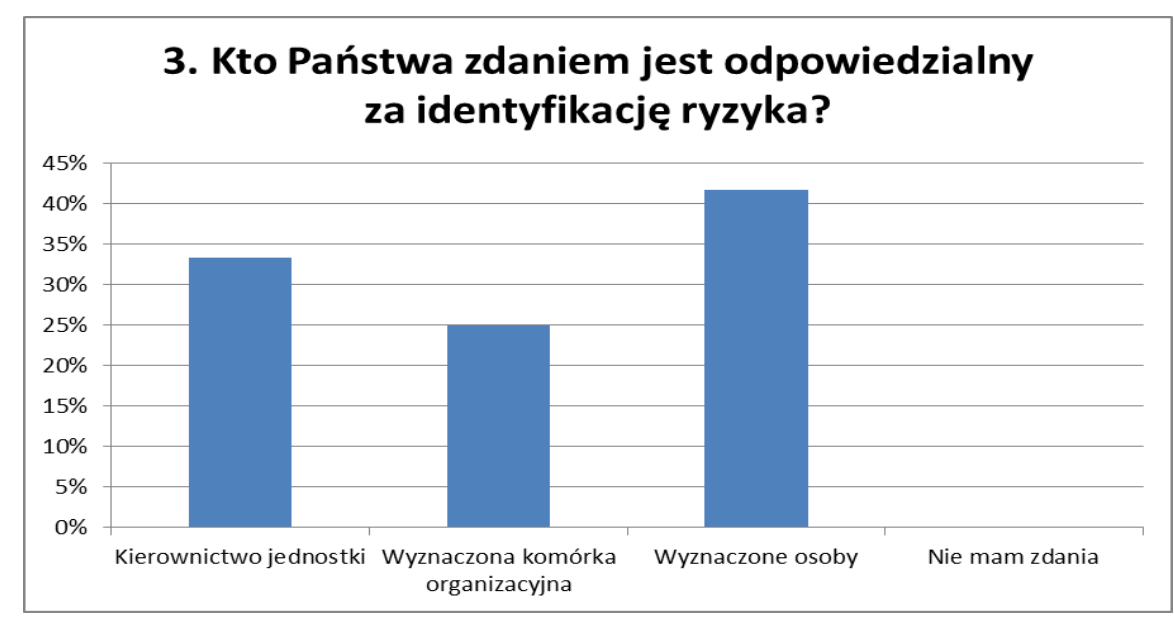

Rysunek 6. Wskazania ankietowanych dotyczące odpowiedzialności za identyfikację ryzyka

Źródło: Opracowanie własne 
Pytanie czwarte dotyczyło największych zagrożeń dla organizacji, biorąc pod uwagę aspekt finansowy. Najwięcej, bo prawie $40 \%$ respondentów odpowiedziało, że są to niewystarczające źródła finansowania. Zmiana wysokości dochodów oraz wzrost kosztów realizacji uzyskały tyle samo odpowiedzi, tj. 15\%. Wzrost wydatków, wielkość zadłużenia organizacji, opóźnienia w realizacji i inne, jakie? - opóźnienia w płatnościach - plasują się na tym samym poziomie: ok. $8 \%$. Wykres z wynikami dotyczącymi tego pytania przedstawia Rysunek 7 .

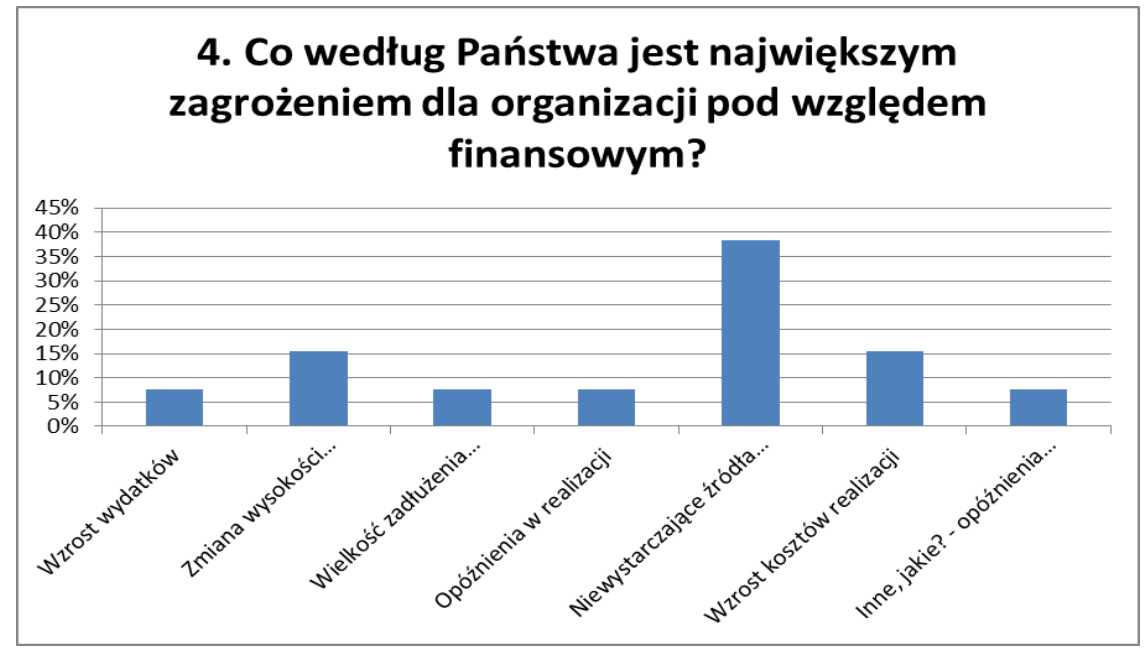

Rysunek 7. Wykres wskazujący główne finansowe zagrożenia dla organizacji

Źródło: Opracowanie własne

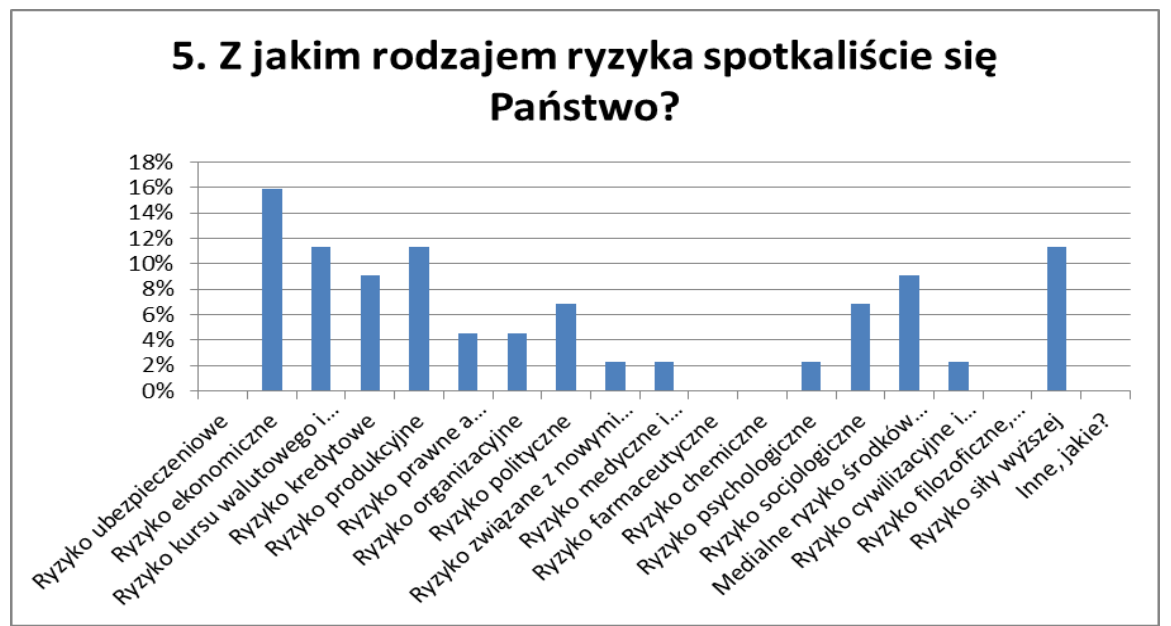

Rysunek 8. Przedstawienie graficzne rodzajów ryzyka, z jakimi spotkali się ankietowani

Źródło: Opracowanie własne 
Kolejne pytanie dotykało kwestii rodzajów ryzyka, z jakimi spotkali się ankietowani. Jak widać na Rysunku 8, najwięcej respondentów wskazało ryzyko ekonomiczne - niecałe 16\%. Kolejnymi odpowiedziami były: ryzyko kursu walutowego i stopy procentowej, ryzyko produkcyjne i ryzyko siły wyższej. Ryzyko kredytowe oraz medialne ryzyko środków przekazu uplasowały się na trzecim miejscu co do ilości odpowiedzi. Kolejnymi odpowiedziami okazały się: ryzyko polityczne oraz ryzyko socjologiczne. Ryzyko prawne i bezpieczeństwo wraz z ryzykiem organizacyjnym znalazły się na przedostatnim miejscu. Ryzyko związane z nowymi technologiami i ekologią, ryzyko medyczne i epidemiologiczne, ryzyko psychologiczne oraz ryzyko cywilizacyjne i kulturowe uzyskały najmniej odpowiedzi. Natomiast ryzyko ubezpieczeniowe, ryzyko farmaceutyczne, ryzyko chemiczne oraz ryzyko filozoficzne, etyczne i religijne nie zostały wskazane przez respondentów.

Pytanie szóste jest bardziej szczegółówe niż pytanie poprzednie. Pokazuje, z jakimi zjawiskami mieli do czynienia ankietowani. Najwięcej, bo 18\% respondentów wskazało ryzyko związane z rozwojem konkurencji. Kolejnymi odpowiedziami są ryzyko inwestycyjne (15\%) i ryzyko regulacyjne związane $\mathrm{z}$ ustaleniem cen (13\%). Ryzyko dotyczące awarii technologicznych, ryzyko wynikające z odpowiedzialności z tytułu świadczenia usług oraz ryzyko uwarunkowane zmianą aktów prawnych dostały $10 \%$ odpowiedzi. Dalej ryzyko zmiany ceny paliwa $9 \%$, ryzyko zmiany cen energii elektrycznej wraz z ryzykiem dotyczącym środowiska naturalnego oraz ryzykiem operacyjnym uzyskały najmniej wskazań, tj. $5 \%$. Nie zostały wybrane dwie odpowiedzi: ryzyko zmiany wielkości produkcji energii elektrycznej oraz inne.

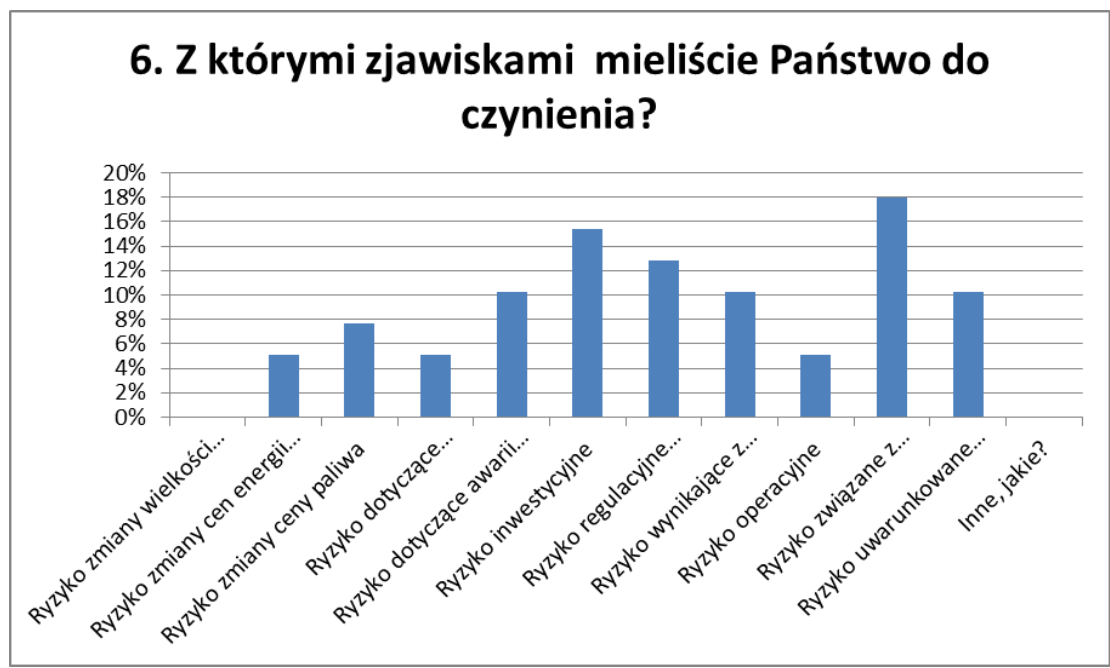

Rysunek 9. Graficzne przedstawienie, z jakimi zjawiskami mieli do czynienia ankietowani

Źródło: Opracowanie własne

Następne pytanie wskazuje na techniki, z jakimi mieli do czynienia respondenci. Odpowiedzi na to pytanie przedstawione zostały na Rysunku 10. Najczęsciej są to wywiady oraz pytania otwarte - stanowiły one $36 \%$ odpowiedzi. Kolejne 
okazały się burze mózgów, które uzyskały $31 \%$ odpowiedzi. Na trzecim miejscu znalazł się wybór ekspertów wewnętrznych i zewnętrznych do przeprowadzenia analizy - w ten sposób odpowiedziało $20 \%$ ankietowanych. W przypadku każdej idei oraz sesji ukierunkowanej, gdzie uczestnicy są dobrani pod kątem różnych aspektów projektu, odpowiedzi zawierały najmniej wskazań, tj. 5\%. Ponownie dwie odpowiedzi nie zostały wskazane, mianowicie: powtórzenie procesu (metoda iteracyjna) oraz inne.

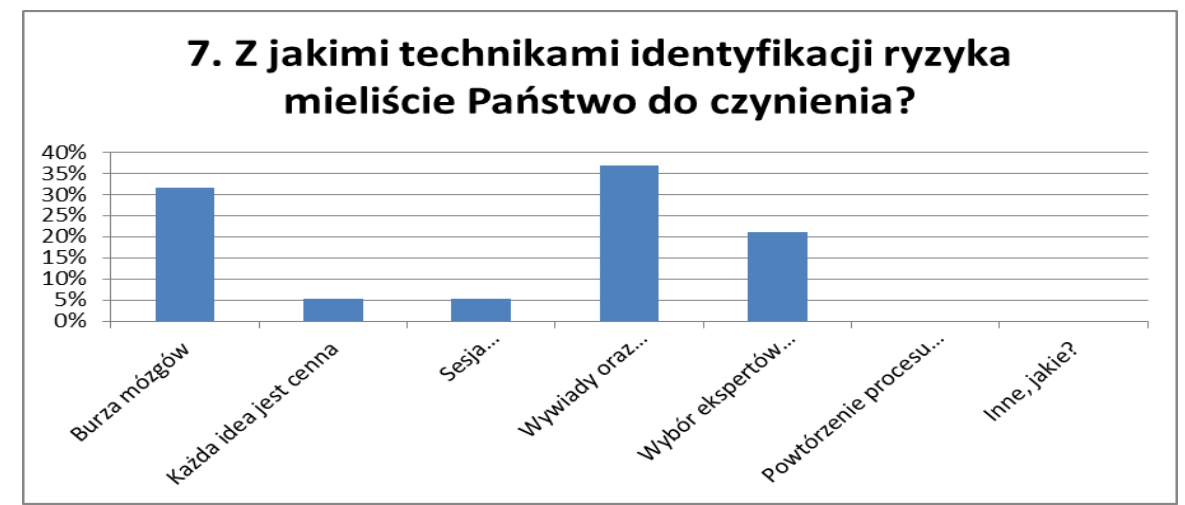

Rysunek 10. Procentowy rozkład występowania technik identyfikacji ryzyka w organizacji

Źródło: Opracowanie własne

Aby przekonać się, z jakimi ilościowymi analizami ryzyka respondenci mieli styczność, zostało zadane pytanie ósme. Patrząc na Rysunek 11, można zauważyć brak jednej zdecywanej odpowiedzi. Co prawda najwięcej, bo $18 \%$ ankietowanych wskazało opinie ekspertów, jednak kolejne odpowiedzi uzyskały $13 \%$, tj. materiały wejściowe, zidentyfikowane ryzyka, dane historyczne oraz symulacje. Lista hierarchii ryzyk wraz z ankietami plasują się na trzecim miejscu z wynikiem $9 \%$. Najmniej, bo ponad $4 \%$ ankietowanych wskazało narzędzia i techniki oraz analizę wrażliwości. $\mathrm{W}$ przypadku tego pytania sporo odpowiedzi nie zostało wybranych, mianowicie: plan zarządzania ryzykiem, lista ryzyk do dalszej analizy i zarządzania, rezultaty innych procesów planowania, analiza drzew decyzyjnych oraz inne.

Pytanie pierwsze otwierające ostatnią część ankiety dotyczyło podejścia do zarządzania ryzykiem w organizacji. Wyniki zostały przedstawione na Rysunku 12. W największej ilości badanych organizacji ryzyko jest regulowane, jeśli odczuwalne są poważne skutki działania danego rodzaju ryzyka - taką odpowiedź wskazało $31 \%$ respondentów. Z kolei $25 \%$ ankietowanych odpowiedziało, że główny nacisk położony jest na identyfikację i ocenienie skali skutków wybranych czynników ryzyka oraz monitorowanie i kontrolowanie kluczowych czynników ryzyka, które jest rozpatrywane jako istotne dla firmy. Zdanie, iż aktywne zarządzanie ryzykiem jest strategiczną umiejętnością konkurowania na rynku, wskazało $12 \%$ ankietowanych przedsiębiorstw. Najmniej, bo $6 \%$, wskazało aktywnie wykorzystywane sytuacje związane z ryzykiem do poprawy wyników finansowo-ekonomicznych. Nikt $\mathrm{z}$ ankietowanych nie podał innego podejścia. 


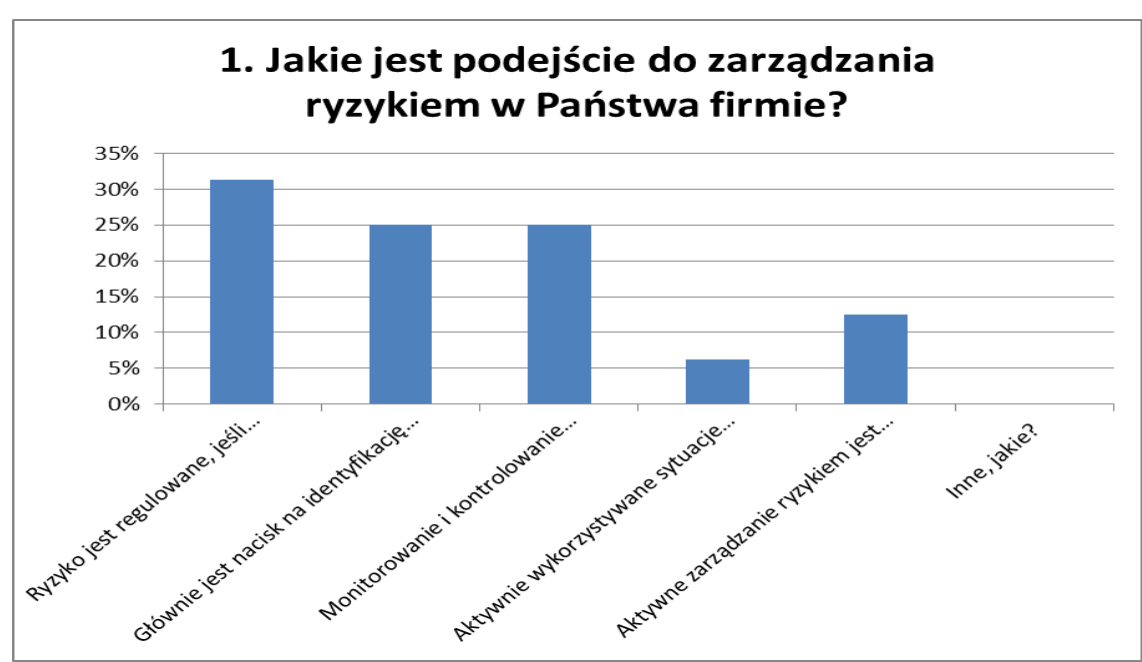

Rysunek 11. Rodzaje ilościowej analizy ryzyka, z jaką spotkali się ankietowani Źródło: Opracowanie własne

3) Pytania dotyczące podejścia do ryzyka oraz barier

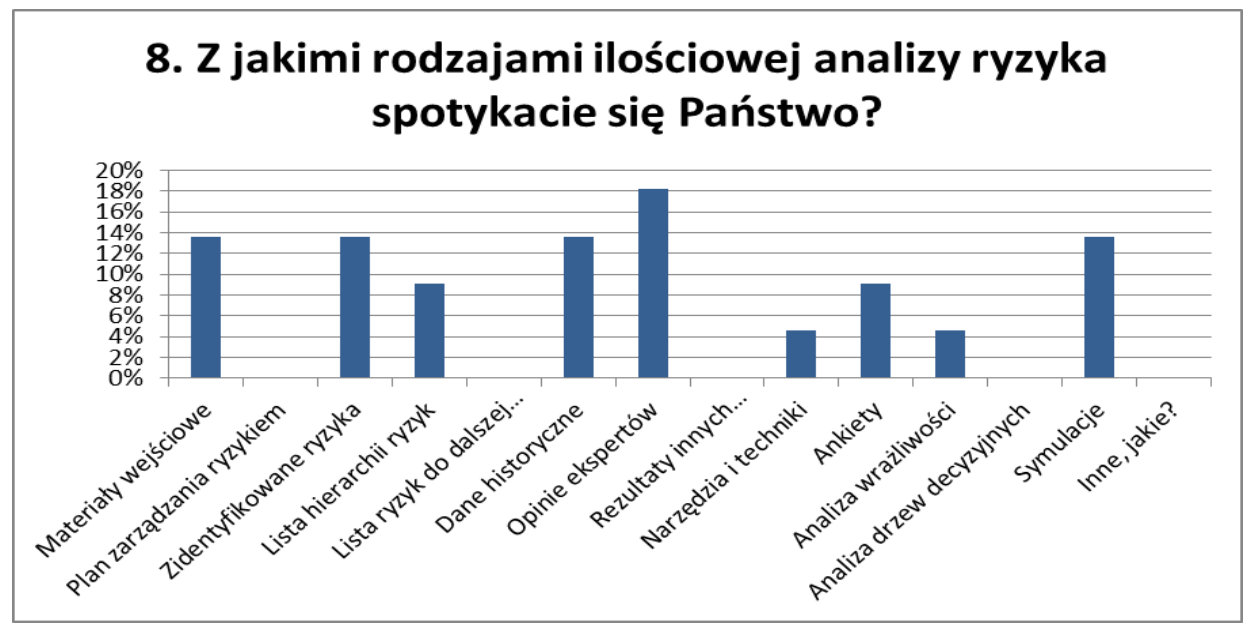

Rysunek 12. Rodzaje podejść do zarządzania ryzykiem w organizacjach ankietowanych

Źródło: Opracowanie własne

W przypadku sposobów zarządzania rozpoznanymi zagrożeniami w firmach ankietowani byli jednogłośni, wskazując trudności związane z określeniem skali ryzyka (38\%) oraz trudność oceny skali zagrożeń (24\%). Również $24 \%$ odpowiedzi uzyskało ocenianie i porównywanie kosztów przeciwdziałania. Najmniej wskazań (7\%) otrzymało ocenianie korzyści oraz korzyści wraz z kosztami. 


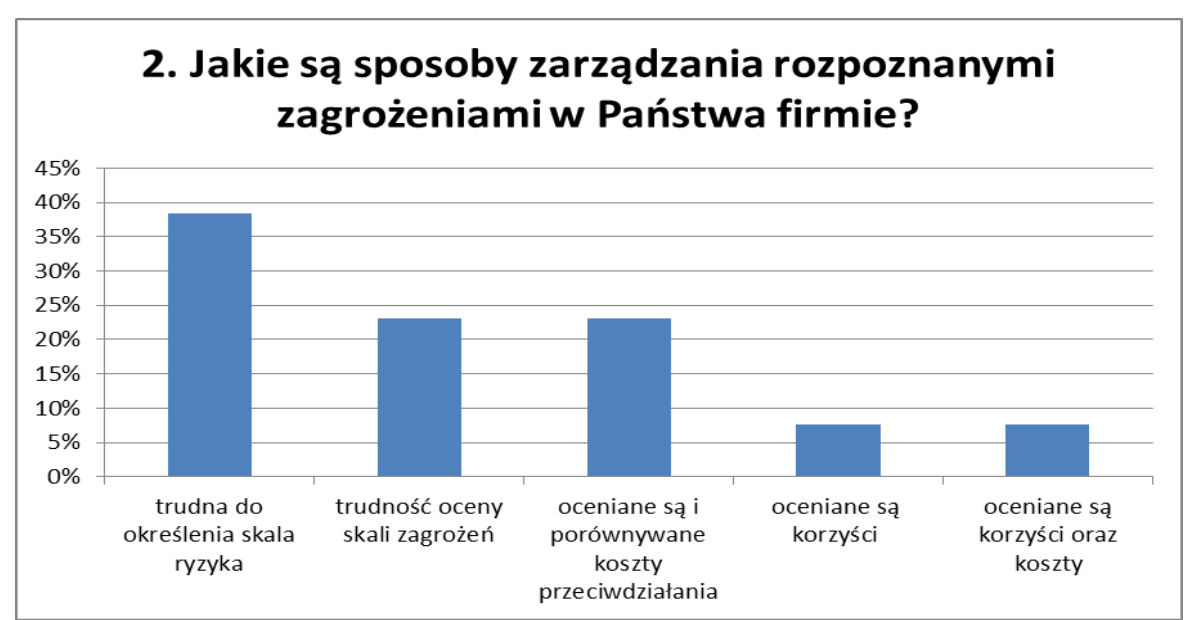

Rysunek 13. Sposób zarządzania zagrożeniami w firmach respondentów

Źródło: Opracowanie własne

Ostatnie pytanie ankiety dotyczyło barier w zarządzaniu ryzykiem w badanych organizacjach. Brak odpowiednich specjalistów okazał się największym problemem badanych - odpowiedź tę wskazało ponad 25\% ankietowanych. Kolejną barierą okazał się brak systemu motywacyjnego (19\%). Dalsze problemy to brak odpowiedniej wiedzy i umiejętności oraz niedostatek środków finansowych (12\%). Niską świadomość wskazało 9\% respondentów. Najmniej (po 6\%) uzyskały odpowiedzi: brak zasobów informacyjnych, brak zasobów materialnych i niematerialnych oraz niewłaściwy system komunikacji wewnętrznej (Rysunek 14).

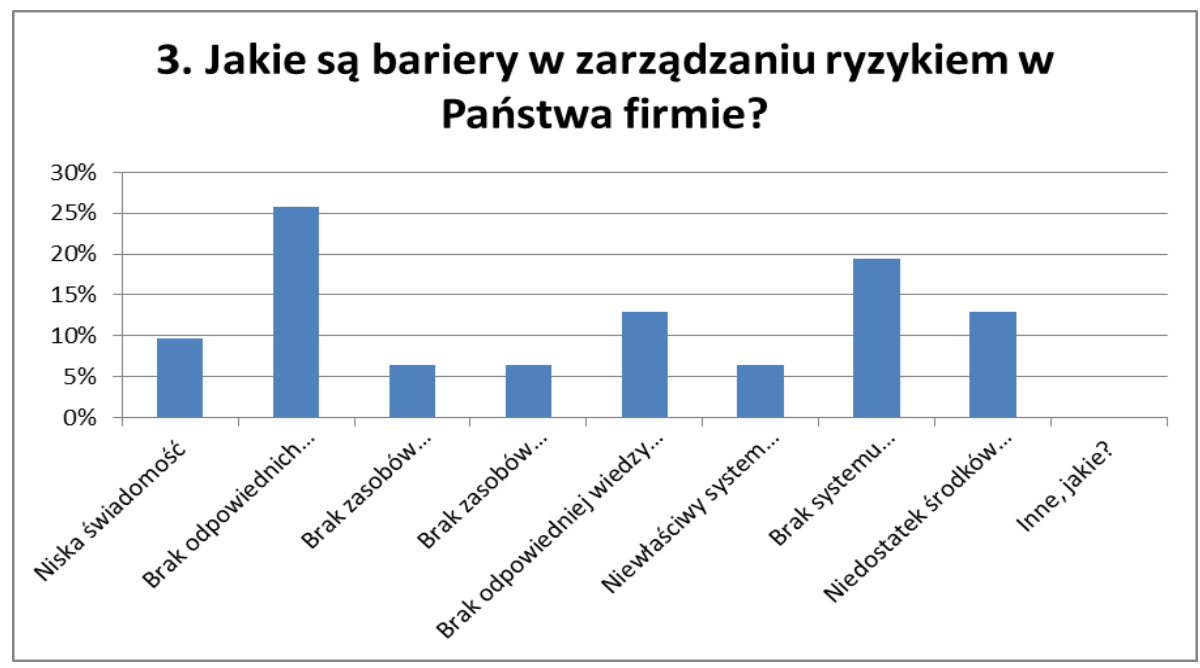

Rysunek 14. Rodzaje barier, jakie występują w organizacjach ankietowanych

Źródło: Opracowanie własne 


\section{Podsumowanie}

Analizując pojęcie ryzyka, można zauważyć, że każdy z badających to zagadnienie twierdzi, że pochodzi ono z niepewności, mając przy tym charakter wymierny. Dzięki temu nie tylko można zidentyfikować istnienie ryzyka, ale również można poddać weryfikacji empirycznej, stosując przy tym odpowiednio dobrane metody pomiaru. Ryzyko posiada możliwość wykonywania pomiaru ze względu na dostęp do informacji, które umożliwiają ocenić ewentualne straty i zyski związane z danym działaniem, czyli daje możliwość oczekiwać odpowiednich skutków przyszłych decyzji.

Nawiązując do przeprowadzonej ankiety, można wyciągnąć kilka głównych wniosków, oczywiście dotyczących organizacji, które wzięły udział w badaniu. Przede wszystkim brak jest w organizacjach specjalistów, którzy już na poziomie identyfikacji ryzyka wsparliby swoją wiedzą organizację. Spowodowane jest to zapewne zarówno brakiem współpracy z ośrodkami naukowymi, jak również niską świadomością. W przypadku dwóch pytań - dość podobnych, dotyczących odpowiedzialności na identyfikację ryzyka - otrzymano rozbieżne odpowiedzi. Dlatego też można wyciągnąć wniosek, że brak jest rozwoju kadry zarządzającej, jak i pracowników w kierunku radzenia w organizacji z ryzykiem. Można jeszcze zauważyć, że najczęściej ankietowani identyfikowali ryzyko ze stratą, co oczywiście nie zawsze ma miejsce.

\section{Literatura}

1. Bernstein P.L. (1997), Przeciw bogom. Niezwykte dzieje ryzyka, WIG-Press, Warszawa

2. Dunaj B. (red.) (1998), Słownik współczesnego języka polskiego, Wilga, Warszawa.

3. Kaczmarek T.T. (2008), Ryzyko i zarządzanie ryzykiem. Ujęcie interdyscyplinarne, Difin, Warszawa.

4. Kaczmarek T.T. (2002), Zarządzanie ryzykiem handlowym, finansowym i produkcyjnym, ODDK, Gdańsk.

5. Malara Z. (2013), Ryzyko i ochrona przed niepowodzeniem $w$ procesie restrukturyzacji przedsiębiorstwa, [w:] Malara Z., Kroik J., Malara M.J., Sobol--Wojciechowska J., Ryzyko. Perspektywa jakościowa, Oficyna Wydawnicza Politechniki Wrocławskiej, Wrocław.

6. Marcinek K. (2001), Ryzyko projektów inwestycyjnych, Wydawnictwo Akademii Ekonomicznej w Katowicach, Katowice.

7. Marcinkowski J. (2009), Ryzyko, jakość prognoz a efektywność inwestowania na rynkach finansowych, Wydawnictwo Uniwersytetu Ekonomicznego w Poznaniu, Poznań.

8. Moore P.G. (1975), Ryzyko w podejmowaniu decyzji, PWE, Warszawa.

9. Pasieczny L. (red.) (1981), Encyklopedia organizacji i zarzadzania, PWE, Warszawa.

10. Piśniak M. (2014), Taksonomia definicji ryzyka. Ryzyko na rynku energii, Wydawnictwo Politechniki Częstochowskiej, Częstochowa.

11. Schroeck W.G. (2002), Risk Management and Value Creation in Financial Institution, Wiley \& Sons, New York.

12. Tarczyński W., Mojsiewicz M. (2001), Zarządzanie ryzykiem. Podstawowe zagadnienia, PWE, Warszawa.

13. Zachorowska A. (2006), Ryzyko działalności inwestycyjnej przedsiębiorstw, PWE, Warszawa. 


\section{ANALYSIS RANGE OF RISKS IN THE SMES}

Abstract: The notion of risk is known to mankind since the dawn of history, at the beginning concerned to ensure adequate conditions for survival, then with growing economy has become inextricably linked to every sphere of human life and business. The aim of the study is the classification and breakdown risk inherent in decision-making processes that are tightly linked to the management. Related is therefore an unknown future, the lack of complete information, which are aimed at eliminating the risk or reducing it. During the next successive processes that take place as a consequence of the decision taken, there may be interference coming from the environment or social environment, causing uncertainty. The aim of the submitted work is an indication of what types of risk are in contact small and medium-sized businesses at every level of decision-making in every industry.

The aim of the submitted work is an indication of what kind of risks they have little contact and medium-sized businesses at every level of decision-making. An additional objective of the study is to show how deficient knowledge of the risk in the surveyed companies.

Keywords: risk, risk types, barriers, SMEs 